\title{
Acquisition of motion events in L2 Spanish by German, French and Italian speakers
}

\author{
Alberto Hijazo-Gascon* \\ School of Language and Communication Studies, University of East Anglia, Norwich Research Park, \\ Norwich NR4 7TJ, UK
}

\begin{abstract}
This article explores the second language acquisition of motion events, with particular regard to cross-linguistic influence between first and second languages. Oral narratives in Spanish as a second language by native speakers of French, German and Italian are compared, together with narratives by native Spanish speakers. Previous analysis on the expression of motion events in these languages showed that Romance languages do not always follow the same pattern, for example, Italian tends to express the component of Path more frequently than French and Spanish. The results of the present study highlight evidence of intra-typological differences, even between languages that are genetically very close. These differences seem to lead speakers to produce cases of conceptual transfer into their second language, Spanish, even when their first language is another Romance language.
\end{abstract}

Keywords: cognitive linguistics; motion events; thinking for speaking; romance languages; Spanish L2

\section{Introduction}

Recent second language acquisition (SLA) studies on motion events have focused on inter-typological differences and the impact of cross-linguistic differences on the development of a rhetorical narrative style in a second language (L2) (Brown 2007; Cadierno 2004; Cadierno and Ruiz 2006; Gullberg et al. 2008; Hohestein, Eisenberg, and Naigles 2006; Navarro and Nicoladis 2005; Negueruela et al. 2004; Stam 2006). The aim of this paper is to show how the first language (L1) can play a key role in the L2 acquisition of motion events, even when both L1 and L2 belong to the same typological and genetic group, as is the case of French, Spanish and Italian. The set of L1s involved in this study thus allows us to observe not only inter-typological but also intra-typological differences. In what follows, we first review the literature on the semantic typology for the expression of motion events and the 'thinking for speaking' hypothesis in relation to L2 acquisition. We then explain the aims and methodology of the study and present its key results, highlighting their significance for our understanding of L2 acquisition processes and implications for pedagogic practice.

*Email: a.hijazo-gascon@uea.ac.uk 


\section{Background}

\section{Motion events and the 'thinking for speaking' hypothesis}

The expression of motion is central to all human languages. Nevertheless, there is considerable cross-linguistic variation within this domain. Talmy (1991, 2000) has established a typological classification of languages based on how they encode motion-semantic components. The four basic components of a motion event are 'Motion', that is, the presence of motion; 'Figure', the moving element; 'Ground', the object with respect to which the Figure moves; and 'Path', the trajectory of the Figure with respect to the Ground. This latter component of Path is crucial to Talmy's typology. In what are known as 'satelliteframed languages' (S-languages), the obligatory component of Path is not encoded in the main verb, but in what Talmy calls a 'satellite', such as out in (1) below. This is the prototypical lexicalisation pattern in Germanic, Slavonic and Finno-Ugric languages, among others. Since these languages tend to encode Path in a satellite, some optional components such as Manner can be expressed by the main verb, for example, float in (1). 'Verb-framed languages' (V-languages), on the other hand, tend to encode Path within the main verb, as shown in Spanish salió 'exited' in (2). This is the case for Japanese, Basque, Romanceand Semitic languages. As a consequence, other non-compulsory components of motion like 'Manner' and 'Cause' are encoded in other elements such as gerunds or adverbials but not in the main verb, for example, flotando 'floating' in (2).

(1) The bottle floated out of the cave

(2) La botella salió de la cueva flotando the bottle exit.[PAST $3^{\text {rd }}$ SING] of the cave float [GERUND] 'The bottle exited the cave, floating'

Some researchers have linked Talmy's typology to Slobin's (1991, 1996a, 1996b, 1997) 'thinking for speaking' hypothesis. This describes the online mental activity during the communication process with effects on attention or memory. According to Slobin, speakers of satellite-framed languages will pay more attention to details concerning Manner of motion. Since this component is easily encodable and frequent in their first language, these speakers will remember Manner details better and probably report them more frequently and with more fine-grained details than speakers of verb-framed languages. 'Thinking for speaking' has been used in the analysis of many languages (see different studies included in Berman and Slobin 1994 and Strömqvist and Verhoeven 2004), providing evidence for Slobin's claims via different methods (translations, oral narratives, written narratives and descriptions) and even through experimental designs (see Filipović 2011; Filipović and Ibarretxe-Antuñano 2015; Ibarretxe-Antuñano forthcoming).

However, recent studies have also shown that Talmy's typology should be considered as a cline, as proposed by Filipović (1999, 2007, 2013). Comparisons of motion expression in different languages have thrown up differences in degree of Manner salience (Slobin 2004, 2006) and Path salience (Ibarretxe-Antuñano 2009a), independent of typological group. Some languages tend to express Manner (or Path) more frequently than others, regardless of whether they are categorised as satellite-framed or verb-framed languages. For example, in the case of Basque, Path is mainly encoded within the main verb, and as such, Basque is clearly classified as a verb-framed language. However, due to other linguistic factors (such as the existence of ideophones, possibility of verb omission, etc.), 
Manner is typically more frequently expressed than in other verb-framed languages (Ibarretxe-Antuñano 2009b).

\section{SLA and cross-linguistic influence}

Expressing motion in a second language is not an easy task. The influence of a learner's L1 on their L2 acquisition has traditionally been studied under the terms 'cross-linguistic influence' (henceforth CLI) and 'transfer' (Jarvis and Pavlenko 2008; Kellerman 1995; Odlin 1989). Not only has transfer been identified at a phonological and semantic level, but it has also been considered at a conceptual level. Jarvis and Pavlenko (2008) claim that the process of SLA involves restructuring the already existing conceptual categories. Conceptual transfer is the reliance during this process on the conceptual categories acquired in the source language. Motion is considered to be one of the areas most prone to conceptual transfer, together with gender, number and emotion (Jarvis and Pavlenko 2008).

As stated above, much of the research on motion events in SLA has focused on the Talmian typology, that is, on L1 users of a verb-framed language learning a satelliteframed L2 or vice versa (Brown 2007; Cadierno 2004; Cadierno and Ruiz 2006; Gullberg et al. 2008; Hohestein, Eisenberg, and Naigles 2006; Larrañaga et al. 2011; Montrul 2001; Navarro and Nicoladis 2005; Negueruela et al. 2004; Nicoladis and Brisard 2002; Stam 2006). Most of these studies have shown how speakers tend to transfer certain L1 patterns into the L2 and this evidence of transfer has been taken as a support for Slobin's 'thinking for speaking' hypothesis. For example, Cadierno (2004) found that Danish learners of L2 Spanish used Spanish adverbials as satellites (as they do in their L1) and then expressed Path semantic components in a more detailed fashion. This specific case of CLI is coherent with Slobin's claim that L1 linguistic resources direct attention to the expression of some components, even in a second language that follows a different trend. Recent studies have focused on speakers whose L1 and L2 belong to the same typological group (Cadierno 2010; Cadierno and Robinson 2009; Cadierno and Ruiz 2006; Filipović and Vidaković ZMakldo 2010; Hijazo-Gascón 2011; Ibarretxe-Antuñano 2004c). The aim of this paper is to contribute to further analysis within this area to support these findings.

\section{Motion events in the languages of this study}

Two important reasons prompted this study. First, the choice of a verb-framed language (Spanish) as the target language is of interest since most of the previous research has focused on satellite-framed target languages. Second, the selection of the source languages (L1s) is of interest because it allows us to observe the effects of both inter- and intra-typological differences on the acquisition of an L2. Spanish, French and Italian belong to the same typological group and the same genetic family, while German does not.

Classical studies in this field consider Spanish as the verb-framed language par excellence (Sebastián and Slobin 1994; Slobin 1996; Talmy 1985, 1991, 2000). More recent studies focusing on French and Italian claim that there are crucial differences between these languages and Spanish, for example, in relation to French prefixes (Kopecka 2004, 2006, 2009) and Italian verb-particle constructions or verbi sintagmatici (Iacobini 2009; Iacobini and Masini 2006). However, frequency of use of these prefixes and verb-particle constructions is not taken into account in these studies. It is important to bear in mind that Talmy's typology is not based on the mere existence of one specific construction in a language, but on predominant (i.e. most frequently used) patterns. 
Recent studies based on real data elicited from narratives and taking frequency into account argue that these intra-typological differences are only true in the case of Italian (Hijazo-Gascón 2011; Hijazo-Gascón and Ibarretxe-Antuñano 2013a, 2013b). In this language, the combinations of verb + particle (e.g. andare via, 'go away', andare su 'go up', andare giù 'go down', etc.) have important consequences for the expression of motion (Cini 2008; Iacobini and Masini 2007a, 2007b; Masini 2005; Mosca 2012; Schwarze 1985; Spreafico 2008). The particles make a significant difference in the expression of Path, because of their frequency and combination possibilities. Although they are frequent and equivalent in meaning to more prototypical verb-framed constructions where Path is expressed in the verb (salire 'go up', scendere 'go down'), they are not as frequent and or as easy to combine with Manner verbs as prototypical satellites. ${ }^{1}$ Due to this low frequency and limited combination possibilities, Italian particles, such as via 'away' or giù 'down', have been considered more as 'pseudo-satellites', rather than as satellites equivalent to those present in Germanic languages (Hijazo-Gascón 2011; HijazoGascón and Ibarretxe-Antuñano 2013a, 2013b). Their presence in Italian seems to be crucial, since Italian speakers express Path significantly more frequently than French and Spanish speakers do, much more in line with speakers of satellite-framed languages (Hijazo-Gascón 2011). As will be explained below, this has important consequences for the acquisition of another L2 Romance language, Spanish, in which similar locative adverbs are not as frequent or as easy to combine (with the exception of pleonastic constructions).

An important difference found in previous research concerns the use of more than one Ground in the expression of a motion event. Satellite-framed languages tend to detail trajectory and encode its different phases in different elements. In the German example (3) below, the trajectory of the motion is expressed in three different elements: nach unten, den Abrund hinunter and in einen Teich:

(3) und die beiden nach unten fielen den Abrund hinunter in einen Teich [08DE] And the [PL] both to down fall [PAST.3SG] the [ACC] cliff there.down in a pond 'and both fell down from the cliff down there in a pond'

Some cases of motion verbs with two Grounds have been found in previous research in some varieties of Spanish (Ibarretxe-Antuñano and Hijazo-Gascón 2011; Sebastián and Slobin 1994), but it seems that this is not the typical way of expressing motion in Spanish. In general, speakers prefer to use just one (or no) Grounds in the event Se cayó (al lago) 'He fell (into the lake)' since the trajectory can be easily inferred. In fact, there were no cases of events with more than one Ground in the narratives by our L1 Spanish control group. Since the Path component is generally codified in the verb, there is no necessity to make all its elements (source, medium and goal) explicit. This is also the case in French but, surprisingly, not in Italian where examples such as (4) are quite frequent:

(4) fa cadere il bambino e il cane giù da un dirupo su un lago [03IT] Make.pRE.3Sg fall.inf the boy and the boy down from a cliff on a lake makes fall the boy and the dog down from a cliff to a lake'2

As previously mentioned, motion is one of the domains where, according to Jarvis and Pavlenko (2008), conceptual transfer is likely to occur. Cross-linguistic influence may thus have various consequences on the rhetorical choices learners make in narrating a story in their L2. It might affect the expression of one component of motion, but not others. The 
aim of this paper is to observe whether the contrastive differences between Romance languages mentioned above impact on the acquisition of L2 Spanish, even in proficient speakers. The results of a control group consisting of native speakers (NSs) will be compared with those of the three L2 groups. The language set chosen allows us to: (1) focus on a V-language as the target language; (2) observe both inter-typological (SpanishGerman) and intra-typological (Spanish-French-Italian) differences and (3) observe intragenetic differences since all the V-languages present in the study are Romance languages.

\section{Motion events in L2 Spanish}

As mentioned earlier, Spanish is generally considered to be the prototypical verb-framed language and most of the studies that deal with Spanish as a second language contrast it with satellite-framed languages (Cadierno 2004; Cadierno and Ruiz 2006; Hohestein et al. 2006; Navarro and Nicoladis 2005; Negueruela et al. 2004; Stam 2006). ${ }^{3}$ One of the difficulties reported in some of these studies for learners of Spanish with a satelliteframed L1 is the lack of a satellite to express Trajectory. Spanish does not have satellites such English out or German raus 'out', nor does it present 'pseudo-satellites' as in the case of Italian (Hijazo-Gascón 2011: 243), for example, che scappa via 'that escapes away' [04IT]. Some combinations of motion verbs and directional adverbs are found in Spanish, but their uses are pleonastic and not frequent enough to be compared to the verbi sintagmatici of Italian. One of the questions posed here with respect to the expression of Path is whether learners will transfer (or try to transfer) their L1 lexicalisation patterns, that is, the encoding of Path outside the main verb, in a satellite in the case of German speakers, or pseudo-satellites in the case of Italians. A possible mechanism by which to do this in Spanish is the use of directional adverbs (arriba 'up', (a)fuera 'out', etc.). Cadierno (2004: 29-30) observes this phenomenon in Danish learners of Spanish, in examples such as (5):

(5) (a) Entonces el perro saltó afuera de la ventana

'Then the dog jumped out of the window'

(b) El ciervo mueve al niño y a su perro abajo en un precipicio

'The deer moves the boy and his dog down in a cliff'

(c) Cuando el chico intenta irse arriba de algunos árboles

'When the boy tries going up some trees'

Cadierno considers that Danish learners might be unconsciously transferring their L1 lexicalisation pattern. This might be the case in (5a), where the component of Path is added as an element outside the main verb. She also suggests the possibility of communicative transfer (Ellis 1994), that is, when learners use transfer as a strategy to express a notion that they do not yet know how to express in the L2. In this case, exemplified in examples (5b) and (5c), they may consciously use a non-directional (or neutral) motion verb, for example, mueve ('moves') or irse ('to go') combined with the directional adverb.

The semantic and syntactic properties of the Spanish directional adverbs that appear in (5) are very different from those of verb-framed languages. However, it seems clear that these are the Spanish structures which are the closest to the satellite-framed language constructions. For this reason, Cadierno (2008a: 261) calls them 'satellisations' of the Spanish constructions. We will discuss later examples of satellisation from our own data, as well as other problematic issues related to the acquisition of motion events in L2 Spanish. 
Research questions

This study focuses on the following research questions related to the acquisition of motion events in a second language:

(1) Does cross-linguistic influence occur in a verb-framed L2 (Spanish) from a verb-framed L1 that is also genetically close to the L2 (French, Italian)?

(2) If so, does conceptual transfer occur in relation to the Manner component or in relation to the Path component?

Although some claims will be made about the acquisition of a verb-framed language by speakers of German (a satellite-framed language), the main focus of this study will be on the acquisition of Spanish by speakers whose first language (French, Italian) is both typologically similar and genetically close.

\section{Methodology}

Data were collected using the oral narrative elicitation task, The Frog Story (Mayer 1968). This is a children's picture book without text, which has been widely used to collect narrative data in a range of languages (Berman and Slobin 1994; Strömqvist and Verhoeven 2004). Four groups of 12 participants _ NSs, respectively, of French, German, Italian and Spanish - participated in the experiment. The speakers of French, German and Italian produced narratives in both their L1 and their L2 Spanish. As confirmed by two external assessors, ${ }^{4}$ their proficiency in Spanish corresponded to the Common European Framework of Languages B2 (Upper Intermediate) level.

All participants were resident in Zaragoza, Spain, at the time of the research. The control group of Spanish NSs (7 men and 5 women, average age 22 years), all came from the area of Aragón and shared the same geographical variety of Spanish. They all reported knowledge of English, with 5 also reporting knowledge of French, although they did not use these languages on a daily basis. The German participants (4 men, 8 women, average age 24 years) came from different parts of Germany. Ten were Erasmus students. The French group consisted of 12 women from different regions in France (average age 22); 10 were Erasmus students. Finally, the Italian group consisted of 9 women and 3 men from different areas of Italy (average age 21 years), and all were Erasmus students.

The research took place at the University of Zaragoza between May 2009 and March 2010. Most of the participants were studying there as part of a study period abroad. Data collection was conducted over two sessions, with one day in between, and was balanced, so that half of each group (excluding the control group) performed the tasks first in their native language and the other half first in their second language. Data were transcribed and coded using the CHILDES system (MacWithney 2000). This double data collection allowed us to contrast participants' L1 and L2 narratives and investigate evidence of cross-linguistic influence from different perspectives. As Jarvis (2000) suggests, this type of study on cross-linguistic influence requires a comparison-based approach since some of the variation in results found in the literature may not due to the phenomenon itself, but rather to lack of methodological uniformity (comparing L1 and L2, or comparing interlanguages of speakers from different L1s). He also highlights the importance of using empirical methods supported by statistical methodology. 
Jarvis (2000: 253-255) considers that there are three different effects of L1 influence:

Intra-L1-group homogeneity in learners' interlanguage performance: this effect is found when learners who speak the same L1 behave in the same manner when they use the L2.

Inter-L1-group hetereogeneity in learners' interlanguage performance: this is found when speakers who speak the same L2 (at the same level, but with different L1) behave differently when they speak or write in the L2.

Intra-L1-group congruity between learners' L1 and interlanguage performance: this effect is found when some uses in L2 are parallel to those in L1.

He stresses the need to ensure that the phenomenon under study is due to the L1 and not due to other factors such as age, proficiency and so on. In order to claim that the behaviour of a L2 learner is the result of L1 influence, the researcher should find evidence of at least two of these effects.

In this paper, we follow this comparison-based approach. First, the focus will be on inter-L1-group heterogeneity in the expression of some subcomponents of motion by comparing the L2 Spanish production of L1 French, German and Italian speakers. Kruskal_ Wallis and Mann-Whitney statistical tests will be used. Second, intra-L1-group congruity between learners' L1 and L2 performances is analysed, comparing the production of each group in their own language and in L2. The statistical test used is Wilcoxon. In both cases, non-parametrical statistical tests are used due to the nature of quantitative data.

\section{Results}

Different data analyses were carried out in order to identify in which cases and to what extent conceptual transfer was present in our corpus. In what follows, we start with an analysis of the motion verbs used by the four groups of participants, and follow this with analyses of the expression of Manner and the expression of Path. We also comment on some examples of expression of causative motion, which we argue reflect cross-linguistic influence.

\section{Motion verbs}

Table 1 presents the total number of verbs together with the number of motion verbs (tokens) produced in the Spanish narratives by the four participant groups. Table 2 reports the numbers of motion verbs (types and tokens) produced by the various groups both in L1 and in L2. Two tallies are given for verb types: Types 1 counts pronominal verbs (verbs with se) as a separate type from their non-pronominal form while Types 2 does not. This reflects the fact that pronominal forms can sometimes be significantly

Table 1. Total motion verbs in Spanish narratives.

\begin{tabular}{lcccccr}
\hline Group & $\begin{array}{c}\text { Total } \\
\text { verbs }\end{array}$ & $\begin{array}{c}\text { Mean per } \\
\text { speaker }\end{array}$ & SD & $\begin{array}{c}\text { Total motion } \\
\text { verbs: tokens }\end{array}$ & $\begin{array}{c}\text { Mean per } \\
\text { speaker }\end{array}$ & SD $_{1}$ \\
\hline Spanish L1 & 576 & 48.00 & 22.65 & 192 & 16.17 & 8.14 \\
Italian L1/Spanish L2 & 488 & 40.67 & 14.82 & 172 & 14.67 & 6.60 \\
French L1/Spanish L2 & 611 & 50.92 & 27.07 & 209 & 17.42 & 8.86 \\
German L1/Spanish L2 & 666 & 55.5 & 28.50 & 174 & 14.42 & 8.15 \\
\hline
\end{tabular}


Table 2. Types and tokens of motion verbs in L1 and L2 narratives.

\begin{tabular}{lccccccc}
\hline & $\begin{array}{c}\text { Spanish } \\
\text { L1 }\end{array}$ & $\begin{array}{c}\text { Italian } \\
\text { L1 }\end{array}$ & $\begin{array}{c}\text { Spanish L2 } \\
(\text { IT) }\end{array}$ & $\begin{array}{c}\text { French } \\
\text { L1 }\end{array}$ & $\begin{array}{c}\text { Spanish L2 } \\
(\text { FR) }\end{array}$ & $\begin{array}{c}\text { German } \\
\text { L1 }\end{array}$ & $\begin{array}{c}\text { Spanish L2 } \\
\text { (DE) }\end{array}$ \\
\hline Types 1 & 41 & 60 & 37 & 53 & 47 & 67 & 46 \\
Types 2 $^{\text {a }}$ & 35 & 53 & 31 & 50 & 42 & 65 & 41 \\
Tokens & 192 & 210 & 172 & 224 & 209 & 213 & 174 \\
\hline
\end{tabular}

${ }^{\mathrm{a}}$ Pronominal verbs not distinguished

different in meaning from non-pronominal equivalents. A list of all the motion verbs used by the participants in their narratives is given in the Appendix.

Spanish NSs used 41 motion verb types and 192 tokens. Among these verbs was a diatopically marked verb, encorrer 'to chase, running', which has been classified as Manner + Path. ${ }^{5}$ This is a characteristic verb in the area of Aragon, where our participants came from.

In their L2 Spanish narratives, Italian speakers produced 37 types of motion verbs with a total of 172 tokens. There were some cases of pronominalisation being overused, for example, *huirse 'escape', a pronominalisation that is neither correct in Spanish nor in Italian (*fuggirsi):

(6) Pero esa rana durante la noche se huyó [05IT]

but that frog during the night se.pro escape.PST.3SG

'But that frog escapes during the night'

French speakers used 47 types of motion verbs in their Spanish narratives and 209 tokens. Another case of the non-target-like *huirse is produced by a French speaker as shown in (7). In French, there are two possibilities to express 'escape': fuir and s'enfuir but not *se fuir.

(7) La rana se huye [03FR]

the frog se.pr escape.pRE.3SG

'The frog escapes'

German speakers produced 46 types of motion verbs in Spanish, with 174 tokens. Another case of *huirse appeared in the production of a German speaker:

(8) Y que se ha huido [01DE]

and that se.PRo have.Aux escape.INF

'And that it has escaped'

The above examples of se being overused with huir by learners regardless of their native language indicates that this is not a case of cross-linguistic influence but a more general process of se overgeneralisation. There were other examples of overused pronominalisation in the data, such as *darse un salto, instead of dar un salto 'jump' in the production of a German speaker:

(9) El perro se da un salto de la ventana [10DE] the dog se.pro give.Pre.3sG a jump from the window 'The dog jumps from the window' 
Another possible case was the verb regresarse 'come back.PRo'. Although regresarse is used frequently in some areas of Latin America (Real Academia Española 2005), it is unlikely to reflect Latin American usage here, as the German speaker demonstrated no other features of Latin American Spanish in her production, either in lexis or pronunciation, and she did not report having had contact with Latin American Spanish. Finally, another interesting example from the L2 corpus was the use of *quitar 'take' with the intended meaning of 'leave'. This usage is not possible in Spanish and might be a case of formal lateral transfer from the German speaker's L3, French quitter 'leave':

(10) Y todas las abejas *quitan del panal [12DE] and all the bees take.3.sg from.the beehive 'And all the bees take from the beehive'

It is interesting to note that the French and German speakers produced a greater range of motion verb types in their L2 narratives than the L1 Spanish speakers (47, 46 and 41, respectively) while the Italian speakers produced the least (37). This result is somewhat unexpected, since the close genetic relationship between Italian and Spanish might suggest that Italian learners would demonstrate a wider lexis in Spanish than the other two groups.

\section{Manner}

Table 3 presents the different types of motion verbs used in Spanish by all four groups, while Table 4 gives further detail concerning Manner verbs. We have chosen to focus our analysis below on Manner verbs only, not including Manner + Path verbs (e.g. caer 'fall'). This follows existing studies where this latter type of motion verb has not been taken into account. The number of Manner + Path verbs produced in our data is fairly similar across the four groups, so their inclusion would probably not in any case imply any differences in our results.

\section{Manner verbs}

Manner verbs used by the Spanish control group were: correr 'run' (5), lanzarse 'throw oneself' (1), empujar 'push' (1), pasear 'stroll' (1), pegar un salto 'jump' (1), saltar ‘jump' (1) and tropezarse 'trip' (1). Italian speakers only used correr 'run' (4), saltar 'jump' (2), volar 'fly' (2) and conducir 'lead' (1). French speakers use correr 'run' (6),

Table 3. Types of motion verbs in Spanish narratives.

\begin{tabular}{lcccc}
\hline & L1 Spanish & L1 Italian & L1 French & L1 German \\
\hline Neutral verbs & $3(22)$ & $2(23)$ & $3(37)$ & $3(30)$ \\
Path verbs & $14(64)$ & $11(54)$ & $13(52)$ & $11(37)$ \\
Manner + Path verbs & $8(70)$ & $10(55)$ & $10(75)$ & $9(62)$ \\
Manner verbs & $7(11)$ & $4(9)$ & $5(10)$ & $8(14)$ \\
Posture verbs & $3(6)$ & $4(10)$ & $6(9)$ & $6(7)$ \\
Other & $6(19)$ & $6(21)$ & $10(26)$ & $11(24)$ \\
Total & $41(192)$ & $37(172)$ & $47(209)$ & $47(174)$ \\
\hline
\end{tabular}

Note: Tokens are given in brackets 
Table 4. Types and tokens of Manner verbs in Spanish narratives.

\begin{tabular}{lccccc}
\hline Group & $\begin{array}{c}\text { Manner verb } \\
\text { types }\end{array}$ & $\begin{array}{c}\text { Type mean per } \\
\text { speaker }\end{array}$ & $\begin{array}{c}\text { Manner verb } \\
\text { tokens }\end{array}$ & $\begin{array}{c}\text { Token mean by } \\
\text { speaker }\end{array}$ & $\begin{array}{c}\text { \% of Manner } \\
\text { verbs }\end{array}$ \\
\hline L1 Spanish & 7 & 0.58 & 11 & 0.92 & $5.64 \_$ \\
$\begin{array}{l}\text { L1 Italian/L2 } \\
\quad \text { Spanish }\end{array}$ & 4 & 0.33 & 9 & 0.75 & $5.23_{\perp}$ \\
$\begin{array}{l}\text { L1 French/L2 } \\
\quad \text { Spanish }\end{array}$ & 5 & 0.42 & 10 & 0.83 & $4.78_{\perp}$ \\
$\begin{array}{l}\text { L1 German/L2 } \\
\quad \text { Spanish }\end{array}$ & 8 & 0.66 & 14 & 1.17 & $8.05_{\perp}$ \\
\hline
\end{tabular}

Table 5. Descriptive statistics for Manner verbs/Language Kruskal-Wallis test.

\begin{tabular}{llcc}
\hline & $N$ & Mean & $\mathrm{SD}_{1}$ \\
\hline Manner verbs & 48 & 0.16 & 0.16 \\
Language & 48 & 2.50 & 1.13 \\
\hline
\end{tabular}

agitar 'shake' (1), andar ‘walk' (1), cargar 'load' (1) and saltar 'load' (1). Finally, German speakers mention correr 'run' (6), volar 'fly' (3), saltar 'jump' (2), andar 'walk' (1), *darse un salto 'jump' (1) and montar 'ride' (1).

The German group used the highest proportion of Manner verbs in their L2 Spanish narratives, as they did in their L1 German (see Hijazo-Gascón 2011 for detailed analysis of their L1 narratives). This is significant in that Spanish is traditionally regarded as a lowManner-salient language (Slobin 2004). The German learners produced eight types, slightly closer to the control group (7) than the other groups (five for French group and four for Italian group). Tokens were also distributed in this order.

Inferential statistic tests were used to compare the narratives of the four groups with regard to the proportion of Manner verbs among the total of motion verbs used. ${ }^{6}$ Descriptive statistics are given in Table 5. As demonstrated by the Kruskal-Wallis test, there were no significant differences among the four groups ( $p=.649, H=1.45, d f=3$ ). The box plot in Figure 1 demonstrates that the differences are small.

Differences between L1 and L2 narratives for the French, German and Italian groups were also analysed for use of Manner verbs. Since the samples were related in these cases, the Wilcoxon test was used. ${ }^{7}$ Descriptive statistics are given in Table 6. Neither the Italian group $(p=.161, Z=-1.14, R=-0.40)$ nor the French group $(p=.593, Z=$ $-.53, R=-0.15$ ) demonstrated any significant differences in the use of Manner verbs between their L1 and L2 narratives. However, significant differences were found when comparing the L1 and L2 narratives of the German group $(p=.002, Z=-3.06, R=$ -0.88). German speakers showed a reduced proportion of Manner verbs in their L2 narratives, where they tended towards the NS pattern. Since Spanish is a V-language, this result might be expected, because it would be quite difficult for these speakers to keep using the same amount of Manner verbs in Spanish as they do in German.

\section{Total Manner expression}

Total Manner expression refers to the proportion of motion events in which the Manner component is included either within the main verb - as in the previous analysis - or 


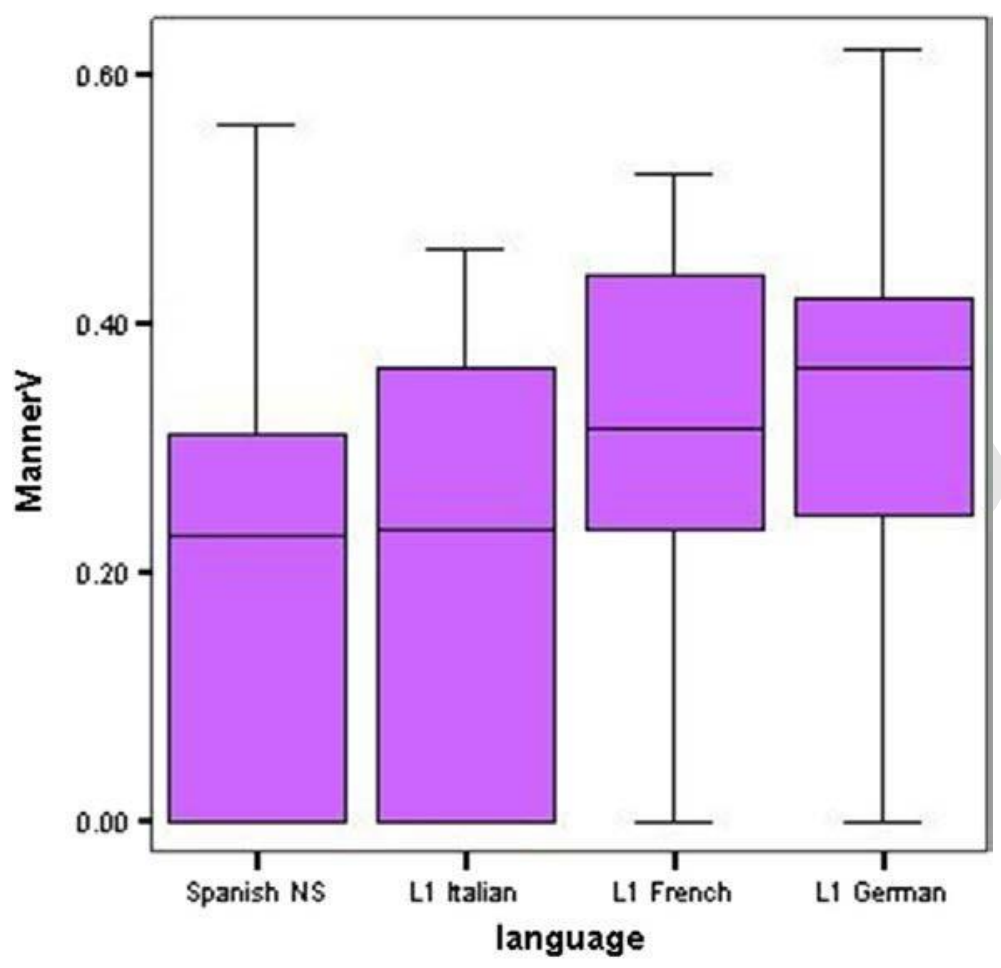

Figure 1. XXX

Table 6. Descriptive statistics for Manner verbs/L1 v. L2 narratives $]$ Wilcoxon test.

\begin{tabular}{lccc}
\hline Group & $N$ & Mean & SD \\
\hline Italian L1 & 12 & 0.21 & 0.18 \\
Italian L1/L2 Spanish & 12 & 0.11 & 0.17 \\
French L1 & 12 & 0.17 & 0.16 \\
French L1/L2 Spanish & 12 & 0.14 & 0.15 \\
German L1 & 12 & 0.61 & 0.13 \\
German L1/L2 Spanish & 12 & 0.20 & 0.19 \\
\hline
\end{tabular}

coded in an adverb, a gerund or a prepositional phrase and so on. This analysis will tell us whether L2 Spanish learners code Manner in elements other than the verb. As Spanish is a V-language, the main verb does not frequently codify Manner information. This analysis is especially relevant in the case of the German group. In German, Manner tends to be expressed much more frequently than in Spanish both in the verb and elsewhere.

The Spanish control group used the following linguistic elements to express Manner outside the main verb: adjective phrases such as asustado 'frightened' (3), cabreado 'pissed off' (1), camuflado 'camouflaged' (1), grande 'big' (1), muy asustado 'very frightened' (1), preocupado 'worried' (1) and todo contento 'super happy' (1); the adverbial phrase perfectamente 'perfectly' (1); prepositional phrases such as de cabeza 'headfirst' (1) and de repente 'suddenly' (1); participles such as enganchado 'hooked' (1) and 
montado 'ridden' (1); gerunds such as corriendo 'running' (3), correteando 'prancing' (3) and volando 'flying' (1). It should be noted that some words included above should not strictly be classified as Manner (e.g. asustado 'frightened'). They are included, however, because they allow the speaker to draw inferences or to create verbal imagery about Manner.

The Italian group produced the adjective phrase enfadadas 'angry' (1); adverbial expressions as boca abajo 'face down' (2); prepositional phrases de repente 'suddenly' (3) and en brazos 'in arms' (1); participles atrapado 'trapped' (1) and encerrado 'enclosed' (1) and gerunds such as corriendo 'running' (3) and saltando 'jumping'(1). French speakers described Manner of motion by means of adjective phrases such as bloqueado 'blocked' (1) and quieto 'still' (1); the prepositional phrase en brazos 'in arms' (1); the participle encerrada 'enclosed' (1) and the gerunds corriendo 'running' (3) and enganchando 'hooked' (1). The German speakers used adjective phrases such as muy felices 'very happy' (1); the adverbial así 'so' (1); prepositional phrases as de repente 'suddenly' (7), en silencio 'quietly' (1), por la cabeza 'headfirst' (1) and the gerund corriendo 'running' (3).

As in the analysis of Manner verbs, no significant differences were found between the three learner groups and the NS group (Kruskal-Wallis $p=.159, H=5.17, d f=3$ ). Descriptive statistics are given in Table 7. L2 speakers did not encode information relating to Manner outside the main verb any more than NSs.

When comparing the L1 and L2 narratives of the same speakers for Total Manner expression, similar results to the previous analysis were also found. Table 8 gives the descriptive statistics. The Wilcoxon test showed no significant differences between L1 and L2 narrratives of either Italian speakers ( $p=.239, Z=-1.17, R=-0.34$ ) or French speakers ( $p=.147, Z=-1.45, R=-0.42$ ). A significant difference was, however, found between the L1 and L2 narratives of the German speakers $(p=.002, Z=-3.06, R=$ stggsosting that the German speakers adapted their L1 preferred rhetorical style towards that of the target language, which favours less Manner information.

Our research suggests, then, that the three groups of learners adapted their narrative style to the characteristic expression of Manner in their L2, Spanish. ${ }^{8}$ French and Italian speakers showed a low level of Manner expression in both their L1 and L2 narratives, so

Table 7. Descriptive statistics for total Manner expression/Language - Kruskal_Wallis test.

\begin{tabular}{lccc}
\hline & $N$ & Mean & SD \\
\hline Total Manner expression & 48 & 0.29 & 0.19 \\
Language & 48 & 2.50 & 1.13 \\
\hline
\end{tabular}

Table 8. Descriptive statistics for total Manner expression/L1 v. L2 narratives _ Wilcoxon test.

\begin{tabular}{lccc}
\hline Group & $N$ & Mean & SD \\
\hline Italian L1 & 12 & 0.35 & .14 \\
Italian L1/L2 Spanish & 12 & 0.25 & .20 \\
French L1 & 12 & 0.32 & .16 \\
French L1/L2 Spanish & 12 & 0.22 & .17 \\
German L1 & 12 & 0.71 & .14 \\
German L1/L2 Spanish & 12 & 0.36 & .17 \\
\cline { 2 - 4 }
\end{tabular}


this might be considered a case of positive conceptual transfer. The German speakers, however, included much more Manner information when narrating in German, both within the main verb and through other structures (62 tokens of Manner verbs, 15 tokens of Total Manner expression). Yet their L2 Spanish narratives did not differ significantly from the other groups. Even though they used the most Manner verbs of all the groups, it still seems clear that they adapted their expression of Manner towards L2 norms.

Path

L2 Spanish speakers seem to exhibit thinking for speaking when expressing the Manner component (Cadierno 2004; Cadierno and Ruiz 2006). In this section, we shall explore whether thinking for speaking is also evident in the expression of Path. The interest in this component is twofold. First, Path is the central compulsory component in every motion event; therefore, it should be harder for learners to adapt to the thinking for speaking of the L2. Theoretically, there should be more cases of conceptual transfer in this component than in the expression of Manner, since the latter is optional. Second, intra-typological differences between Italian, French and Spanish have been found in relation to the expression of Path. As mentioned earlier, previous research into L1 rhetorical style offers evidence that Italian speakers had similar Path expression rates to those of German speakers and both these groups had significantly higher rates than French and Spanish speakers. If the significant differences found in relation to Italian and German speakers using their L1 are maintained in their L2 Spanish, this can be considered as evidence of conceptual transfer due to both inter- and intra-typological differences.

First, we consider possible cases of satellisation in L2 Spanish. These are similar to those described in Cadierno (2004) for Danish learners of Spanish. Second, we analyse the narratives for the component of Ground, identifying the proportion of motion verbs which are followed by one or more 'Grounds' expressing the trajectory of the motion event, for example, El perro se cayó al suelo 'The dog fell to the ground' (Plus Ground 1); El perro se cayó de la ventana al suelo 'The dog fell from the window to the ground' (Plus Ground 2), versus the proportion of motion verbs where there is no indicator of Ground for example, El perro se cayó ‘The dog fell’ (Minus Ground).

\section{Satellisations in L2 Spanish}

Although Cadierno (2004) found several cases of satellisations in L2 Spanish, our corpus does not contain any instances of satellisations per se. There are some rare instances of nontarget-like constructions where a motion verb appears in combination with an adverb, as illustrated in the German learner's example in (11):

(11) El ciervo no puede correr más adelante [12DE]

the deer no can.pRE.3Sg run more forward

'The deer cannot run more forward'

Here, adelante 'forward' is an adverb, but this combination is not as clear as the examples of satellisation found in Cadierno (2004). It can hardly be considered a case of communicative transfer. Correr más adelante 'run more forward' is in any case a dubious combination in Spanish. In the other possible candidates for satellisation, there are no directional adverbs, but rather a neutral motion verb with a Ground (generally a prepositional phrase) implying a particular directionality or spatial relations as in (12): 
(12) E intenta ir sobre la piedra [08IT] And try.PRE.3SG go.INF on the rock

'And he tries to go on the rock'

Talmy in fact differentiates between satellites and prepositions; ${ }^{9}$ the latter are different surface forms, and therefore (12) cannot be considered a case of satellisation.

In the case of Italian learners, some constructions were found in our data which, though understandable, do not correspond to target language usage, but could not be considered as satellisations either:

(13) (a) El niño comenzó a ir lejos de su casa [09IT] the boy start.pst.3sg to.prep go far from his home 'The boy started going far from his house'

(b) Lo deja dentro de un lago [11IT] it leave.PRE.3SG inside of a lake 'He leaves it inside of a lake'

These cases are the closest to those used by the Danish learners in Cadierno's (2004) study in that they combine a motion verb and an adverb. However, lejos 'far' and dentro 'inside' are quite different from satellites such as down in English or pseudo-satellites such as via 'away' in Italian. They are not as frequently used or as easy to combine in verb-particle constructions in Spanish. On the basis of Cadierno's (2004) analysis, more satellisations in L2 Spanish would have been expected (especially in the case of the German and Italian learners). This lack of satellite transfer might be due to the higher L2 proficiency of the learners in the present study, or alternatively, to their psychotypology, that is, the distance they perceived between their two languages (Kellerman 1995). However, as will be seen in the following sections, what the learners do transfer is a higher elaboration of Path in their expression of motion events in L2 Spanish.

\section{Ground}

Slobin proposes the following analysis to describe the characterisation of Path in relation to the Ground. 'Minus Ground' verbs occur when the main verb is not followed by any element that codifies Ground information as in (14):

(14) Finalmente el panal cae [07FR]

Finally the beehive fall.PRE.3SG

'Finally the beehive falls'

'Plus Ground' verbs occur when the main verb links to at least one extra element which codifies the Ground component, independently of the nature of the Ground, that is, whether it is the source, the goal or the medium of the movement. For example, in (15), the prepositional phrase del árbol 'from the tree' indicates the source of motion:

(15) y se cae del árbol [04FR]

And refl fall.pRE.3SG from.the tree

'And he falls from the tree'

Table 9 shows the global data for the analysis of Ground expression for each group. The German learners show the highest level of expression of Ground in Spanish, with 64\% of 
Table 9. Plus Ground and Minus Ground verbs in Spanish narratives.

\begin{tabular}{|c|c|c|c|c|c|c|}
\hline & $\begin{array}{c}\text { +Ground } \\
\text { tokens }\end{array}$ & $\begin{array}{l}\text { +Ground } \\
\text { mean per } \\
\text { speaker }\end{array}$ & $\begin{array}{c}+ \text { Ground } \\
\%\end{array}$ & $\begin{array}{c}\text {-Ground } \\
\text { tokens }\end{array}$ & $\begin{array}{l}\text {-Ground } \\
\text { mean per } \\
\text { speaker }\end{array}$ & $\begin{array}{c}\text {-Ground } \\
\%\end{array}$ \\
\hline L1 Spanish & 100 & 8.33 & 51 & 95 & 7.92 & 49 \\
\hline $\begin{array}{l}\text { L1 Italian/L2 } \\
\text { Spanish }\end{array}$ & 102 & 8.5 & 59 & 71 & 5.92 & $41_{\lambda}$ \\
\hline $\begin{array}{l}\text { L1 French/L2 } \\
\text { Spanish }\end{array}$ & 94 & 7.83 & $45_{\perp}$ & 115 & 9.58 & $55_{\lambda}$ \\
\hline $\begin{array}{l}\text { L1 German/L2 } \\
\text { Spanish }\end{array}$ & 111 & 9.25 & $64_{\perp}$ & 62 & 5.17 & 36 \\
\hline
\end{tabular}

Note: All percentages have been rounded up.

motion events including some information about Ground, compared with 59\% for the Italian group and 51\% for the Spanish control group. The NSs show a balanced usage of + Ground and -Ground motion event descriptions. Only the French speakers show a higher proportion of -Ground motion event descriptions (55\%) than NSs. The mean of +Ground cases per participant is higher for the German learners (9.25) and lower for all Romance language speakers: Italian speakers showed a mean of 8.5, native Spanish speakers 8.33 and French speakers 7.83. It should be noted that the inclusion of linguistic elements expressing Ground is not a question of grammatical accuracy, but relates to the way that a speaker choses to express a motion event. What is at stake here, then, is learners' variation from the preferred rhetorical style of a language and its patterns of usage, rather than the grammaticality of their utterances (Figure 2).

A Kruskal-Wallis test resulted in a statistically significant difference $(p=.016(H=$ $10.31, d f=3$ ) between the four groups. When contrasting the groups using the MannWhitney test, the significant difference between the control group and the German group was a trend, but close to the $\alpha$ level $(p=.027, Z=-2.18, R=30.50)$. There was no significant difference between the Spanish control and the Italian group ( $p=.260, Z=-1.17, R=47.00$ ) and between the Spanish control and the French group ( $p=.316, Z=-1.02, R=49.50$ ). Table 10 and Figure 3 show the results.

Inter-typological differences appear significant here, with German L2 speakers expressing more detail overall for the Path component than the Spanish and French (i.e. Romance language) speakers. However, despite Italian being a Romance language, no significant difference is found between the expression of Path by Italian speakers and by German speakers. Italian speakers seem to follow their L1 pattern when expressing Path (HijazoGascón 2011). The fact that their expression differs significantly from the French group can support the claim that this is a case of cross-linguistic influence. Neither French nor Italian speakers, however, show significant differences with the Spanish NS, so they seem to readjust their thinking for speaking in the L2. Although both groups of Romance learners seem to follow the preferred rhetorical style for the target language (neither French nor Italian speakers present significant differences from the control group), they still retain their separate L1 preferences for Path description; that is, expressing Path through more than one piece of information in the case of Italian and none in the case of French. This seems to be a clear case of cross-linguistic influence, since it is an effect of inter-group heterogeneity in the interlanguage.

In order to confirm this conclusion, we ran further statistical tests on the Plus Ground verb analysis comparing the same speakers in their L1 and their L2. Descriptive statistics 


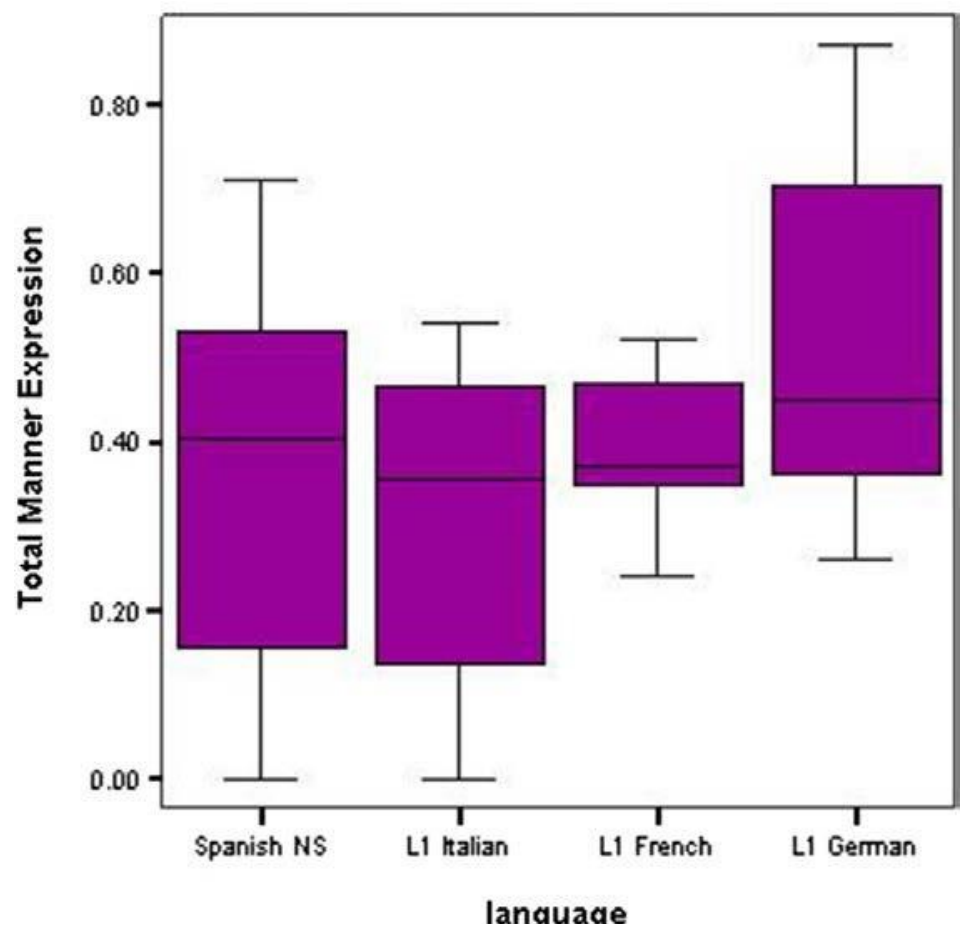

Figure 2. Percentage of total Manner expression in Spanish narratives.

Table 10. Descriptive statistics for \pm Ground verbs/Language Kruskal-Wallis.

\begin{tabular}{llcc}
\hline & $N^{\mathrm{a}}$ & Mean & $\mathrm{SD}$ \\
\hline +Ground & 47 & 0.85 & 0.17 \\
Language & 47 & 2.53 & 1.12 \\
\hline
\end{tabular}

${ }^{\mathrm{a}}$ One outlier was found in the NS group and deleted.

are given in Table 11. Results from the Wilcoxon test support our conclusion. German speakers did not show significant differences ( $p=.638, Z=-.47, R=-0.12$ ) between their L1 and L2 discourse. They simply followed their L1 pattern when speaking in their L2 and thus differ from Spanish NSs. French speakers show no significant differences between L1 and L2 $(p=.638 Z=-.47, R=-0.12)$ and there was only a statistical trend suggesting difference in the case of Italian speakers $(p=.110, Z=-1.6$, $R=-0.46)$.

\section{+ Ground with more than one element}

Some examples of main motion verbs with two dependent Ground elements were found in the L2 Spanish data. Similar cases were also found in the L1 (German and Italian) data, as illustrated in (3) and (4) above. In contrast, none of the Spanish NSs expressed Path using more than one element. However, this does not mean that the L2 speakers' constructions are 


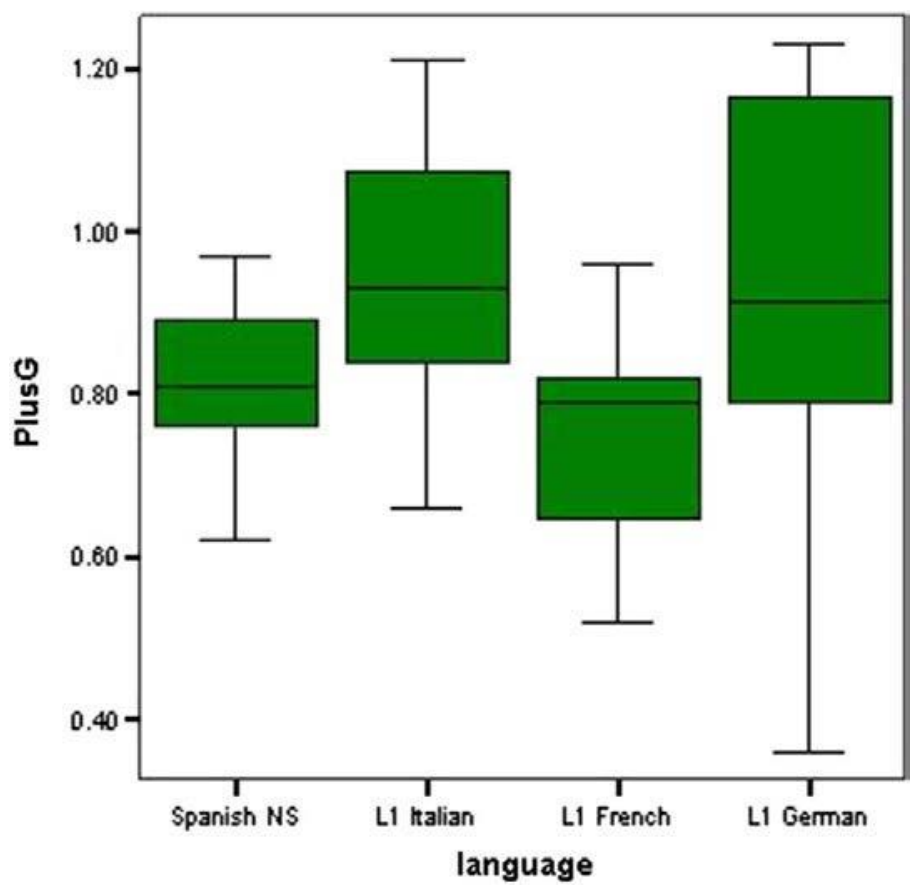

Figure 3. Percentage of Plus Ground verbs in Spanish narratives.

Table 11. Descriptive statistics for Plus Ground verbs/L1 v. L2 narratives - Wilcoxon test.

\begin{tabular}{lccc}
\hline & $N$ & Mean & SD \\
\hline Italian L1 & 12 & 1.00 & 0.13 \\
Italian L1/L2 Spanish & 12 & 0.89 & 0.17 \\
French L1 & 12 & 0.76 & 0.20 \\
French L1/L2 Spanish & 12 & 0.75 & 0.12 \\
German L1 & 12 & 0.91 & 0.14 \\
German L1/L2 Spanish & 12 & 0.95 & 0.23 \\
\hline
\end{tabular}

agrammatical in Spanish; just that they are not characteristic of NS usage. As might be expected, the examples come from German (16 and 17) and Italian (18 to 20) learners:

(16) y cae en el suelo de la ventana [08DE] and fall.PRE.3SG in the ground from the window 'and falls in the ground from the window'

(17) y el perro cayó de la ventana al jardín [11DE] and the dog fall.pST.3Sg from the window to the garden 'and the dog falls from the window to the garden'

(18) y se cae desde una pequeña montaña dentro de un lago [01IT] and se.Pro fall.pre.3sG from a small mountain inside of a lake 'and falls from a small mountain inside of a lake' 
(19) y lo lleva desde la roca a un despeñadero [02IT] and it.acc take.pre.3sg from the rock to a precipice 'and takes it from the rock to a precipice'

(20) y el niño y el perro cayeron del barranco hasta dentro de un río [09IT] and the boy and the dog fall.pst.3PL from.the cliff until inside of a river 'and the boy and the dog fell from the cliff to inside of a river'

\section{Caused-motion constructions}

An interesting example of cross-linguistic influence which emerged in our data was the use of a special type of caused-motion construction. French and Italian learners frequently used the auxiliary verb hacer 'make/do' and the infinitive of a motion verb to express a causative motion in L2 Spanish, as shown in examples (21) and (22):

(21) (a) y el perro hace que se caiga el panal [02IT] and the dog make.PRE.3sG that se.pro fall.suBJ.3SG the beehive 'and the dog makes the beehive fall'

(b) y hace caer al niño y al perro en un estanque [10IT] and make.PRE.3sG fall.INF the boy and the dog in a pond 'and makes the boy and the dog fall in a pond'

(22) (a) y hace caer a una colmena [02FR] and make.pRE.3sg fall. InF to a beehive 'and makes it fall to a beehive'

(b) pero el búho lo hace caer del árbol [08FR] but the owl it.AC make.PRE.3SG fall.INF from.the tree 'but the owl is made fall from the tree'

Most of the occurrences of this construction were found with the verb caer, but some cases with non-motion verbs were also found in L2 Spanish:

(23) mientras el perro él se hace picar por las abejas [02FR] while the dog he se.pro make.PRE.3SG sting.INF by the bees 'while the dog gets himself stung by the bees'

(24) y se hace perdonar [06FR]

and se.pro make.pre.3Sg forgive 'and he gets himself forgiven'

This construction is not found in Spanish; ${ }^{10}$ there were no cases in the NSs data. Nevertheless, its use does not hinder fluent communication; a Spanish NS would be able to understand perfectly well the learner's intended meaning, but would not use such constructions as part of his/her rhetorical style. Following Kellerman's terminology, this construction can be taken as an instance of 'transfer to nowhere', that is, a transfer of L1 linguistic elements that do not correspond to the L2. This construction is, however, very frequent in French and Italian as illustrated in the examples 26 and 27 below from L1 narratives. Eight tokens were elicited from 4 different Italian speakers and 13 tokens from 6 French speakers 
(these speakers were not necessarily the same speakers who transferred this construction into their L2 Spanish).

(26) (a) fa cadere il bambino e il cane giù da un dirupo su un lago [03IT] Make.pRE.3SG fall.inf the boy and the dog down from a cliff on.pREP a lake 'He throws the boy and the dog down from a cliff to a lake'

(b) fa uscire delle api [09IT] and make.PRE.3SG exit.INF the.PART bees 'and he makes the bees go out'

(27) (a) le cerf fait tomber le petit garçon dans l'eau [06FR] The deer make.pRE.3sg fall.inf the little boy in.pREp the.water 'The deer makes the boy fall into the water'

(b) le petit garçon se fait jeter par la fenêtre [06FR] the little boy se.rEFL make.PRE.3SG throw through.PREP the window 'The little boy gets himself thrown through the window'

The examples with hacer caer 'make fall' are a clear case of conceptual transfer from L1 to L2 in the motion domain. Moreover, this pattern shows a clear intra-typological difference between Spanish on the one hand, and Italian and French, on the other. Its occurrence in speakers with a B2 level of proficiency is a good example of how Romance language speakers may still follow their L1 patterns when expressing motion, even in cases like this causative construction in which the result is a 'trans- ferto-nowhere'.

\section{Discussion}

This study presents two key original findings, namely inter-typological differences in the acquisition of L2 Spanish between German speakers on the one hand and speakers of French and Italian on the other, and the intra-typological differences found between Italian and French learners of Spanish. These differences no doubt reflect processes in the acquisition of L2 Spanish by these learners and thus this study has potential implications for the teaching of languages.

In the case of inter-typological differences, our results on the expression of Manner do not show any significant differences between the German group and either the Spanish control group or either of the two other Romance language learner groups. Furthermore, our results also show that German learners significantly change their Manner expression depending on whether they are narrating in their L1 or their L2 Spanish. When expressing Path, however, the German group showed no significant differences between L1 and L2 narratives. We thus conclude that in relation to Manner, there is a change in their thinking for speaking to adjust to the different rhetorical style of Spanish NSs. These results are in line with previous research on Danish learners of Spanish (Cadierno 2004; Cadierno and Ruiz 2006). However, an important difference with these latter studies was the absence of instances of 'satellisation' in our data. This might be due to the context of instruction (the linguistic immersion of our participants), the level of proficiency of the participants, or to the data elicitation procedure (oral elicitation). In Cadierno's studies, the data were elicited in the L1 setting (Denmark), the level of proficiency was lower and informants wrote their answers. When comparing the Spanish narratives by speakers of Romance languages (L1 Italian, L1 French and L1 Spanish), no intra-typological differences were 
found in the expression of Manner. Nor significant differences were found when comparing the narratives of the same speakers in their L1 and L2.

The results for the expression of Path are much more complex. First, some differences were found between the three Romance languages: the L1 narratives of Italian speakers presented a much more detailed expression of this component than the other L1 groups. However, the L2 narratives in Spanish by both the French and Italian speakers showed no significant differences in terms of Path from the native Spanish speakers but significant differences were found between the two learner groups themselves (French L1/Spanish L2 v. Italian L1/Spanish L2). It could be argued that, as in the case of Manner for the German learners, there was a readjustment to the thinking for speaking of the L2, and as a consequence, cross-linguistic influence cannot be claimed. But this would be only partially correct. It is true that Italians seemed to be on the way to readjustment (the difference between their L1 and L2 narratives was a trend, though not significant), but their L2 narratives were significantly different from those of the French learners. This result suggests that L1 influence can still be claimed, even if both groups of learners express themselves accurately in the $\mathrm{L} 2$.

The existence of transfer is supported by evidence in both between-groups and withingroups analysis, which complies with Jarvis' (2000, 2010) methodological recommendation that empirical research on transfer should be standardised by means of a multiple comparison-based model. Our data provide evidence for two L1 effects: inter-L1-group heterogeneity in L2 Spanish, and intra-L1-group congruity between learners' L1 and their performance in the L2. As shown above, where we identified a significant difference between the different groups, this was congruent with the results coming from the comparison of L1 and L2 performance by the same speaker.

Thus, results on the expression of Path seem to confirm the existence of a positive transfer in the case of French speakers since the expression of this component is the same in French and Spanish. Italian speakers were of particular interest as, on the one hand, their L2 expression of Path was consistent with the TL rhetorical style; on the other hand, it could also be seen as reflecting their L1 rhetorical style which is closer to that of satellite-framed languages. Their L1 verb-particle constructions, for example, andare via 'go away', allow them to express Path in more detail and more frequently than in other Romance languages such as French and Spanish. Cross-linguistic influence can thus be claimed here as the Italian speakers typically expressed motion events using two Grounds in L2 Spanish, just as the German speakers did, while French learners and Spanish NSs did not.

Finally, cases of transfer across Romance languages were also found in relation to causative motion constructions. These constructions, using fare 'make' in Italian and faire 'make' in French with an infinitive, highlight an intra-typological difference with respect to Spanish, where such constructions, though understandable, are not used. The frequent presence of constructions using the verb hacer 'make' in the Spanish L2 narratives of the Italian and French learners is remarkable. These are cases of 'transfer to nowhere' (Kellerman 1995). In this sense, what Kellerman (1995) calls psychotypology seems to play a crucial role in the domain of motion, as shown by previous research (Cadierno 2004; Cadierno and Ruiz 2006). The linguistic distance perceived by speakers between their L1 and L2 when their languages are very close can result in a positive transfer, but it can also trigger transfer to nowhere, when the similarities between both languages are overestimated. 


\section{Conclusions}

This paper examined the expression of motion events in L2 Spanish by French, German and Italian learners. In the analysis of Manner, inter-typological differences were found between the L2 Spanish narratives produced by German learners and those of Romance language learners and NSs. In the case of Path, not only were inter-typological differences found, but also intra-typological. Although no significant Path differences were found between the L2 narratives of the learner groups on the one hand and the NS control group on the other, there was a significant difference between French and Italian L2 Spanish narratives with the latter group expressing Path more frequently and in greater detail. Italians (and Germans) also provided cases of complex Path (i.e. expressing more than one Ground in a complex trajectory). These findings suggest cross-linguistic influence in the expression of motion, even at a high proficiency level (B2). Further evidence of CLI was provided by the consistent use by French and Italian speakers of causative constructions with the verb hacer 'make'. These constructions were not present at all in the L1 Spanish narratives.

Our results thus support the view that cross-linguistic influence can play a significant role in the expression of motion in a second language. As stated by Jarvis and Pavlenko (2007), this domain seems to be prone to the appearance of conceptual transfer. With motion being such a key experiential domain, it seems difficult to avoid (though not necessarily impossible) the influence of the first language. Previous research on intra-typological variation among the languages investigated here (Hijazo-Gascón, 2011; Hijazo-Gascón and Ibarretxe-Antuñano 2013a, 2013b) found important contrasts that can have a significant impact on SLA. It should be noted, however, that this influence does not necessarily imply grammatical inaccuracy or communicative problems; it may simply be revealed in variation from the typical rhetorical style of target language speakers.

The results presented in this article confirm the importance of studying differences between languages within the same typological group and the potential for cross-linguistic influence in the acquisition of motion events. The results also support the view that the acquisition of typologically and genetically close languages is not necessarily 'easier' than the acquisition of typologically and genetically distant ones. Positive and negative transfer and the learner's own perception of the typological distance or psychotypology (Kellerman 1995) all play a major role in the acquisition process.

Further lines of research for the future would be to study transfer in the other direction, that is, L1 Spanish speakers whose L2 is French, Italian or German and other semantic domains apart from motion would be worth investigating. From a more applied perspective, this study has a number of pedagogical implications. As Cadierno (2008) suggests, theoretical studies in cognitive linguistics (and specifically in motion events typology) allow a shift of perspective in the way that pedagogical implementation is understood. Cadierno (27/ 08 :gives four key reasons to explicitly teach motion constructions: (1) Talmy 's typology shows systematic cross-linguistic differences that make L2 acquisition of this construction potentially challenging; (2) Slobin's (1996a, 1996b, 1997, 2000, 2003, 2004, 2006) studies show that these typological differences have important consequences in relation to discourse preferences; (3) learners seem to establish non-target-like formmeaning mappings with regard to motion constructions in both production and comprehension and (4) motion constructions are challenging to acquire especially for L1 V-language speakers learning an L2 S-language. With respect to this latter observation, however, the results of this paper also show that the expression of motion is potentially challenging even for L1 V-language speakers acquiring another V-language as an L2. 
Cadierno (2008) goes on to propose a comprehensive pedagogical intervention in line with the focus-on-form approach (Long 1991), which seeks to integrate focus on linguistic form within communicative activity. She suggests that explicit instruction could focus on promoting awareness of the differences in expression of motion between the languages involved (in her case Danish and Spanish) and that Total Physical Response (TPR) could be of value here. TPR is a comprehension-based approach to language teaching based on the coordination of speech and corresponding action (Asher 1997); both instructor and students would, for example, act out given motion constructions. In the case of production activities, Cadierno (2008: 283) proposes several in-pairs activities, such as a one-way picture drawing task with one student describing an action and the other drawing it; a one-way map direction task with one student giving directions and another drawing the route; a two-way 'spot the difference' task with students identifying differences in motion events represented in two pictures and a two-way picture sequencing task requiring students to reconstruct a story.

Other activities oriented to the learning of L2 Spanish grammatical elements following the principles of focus on form can be found in Miquel-López and Ortega-Olivares (2014). Further activities informed by cognitive linguistics might include a consciousness-raising activity inviting learners to identify motion verbs in a given text and then classify them as Manner or Direction verbs. Students could be also asked to compare two narratives describing the same event, one including a lot of Path description (which in Spanish would be repetitive and redundant with Path verbs) and another describing the event in a more target-like fashion. Production activities could also be designed; for example, students could be required to describe a video in which different people move to and from different places in different ways, or they might engage in a 'car race' role-play game in pairs requiring a 'co-pilot' to describe to a 'driver' the fastest way to arrive at a given destination on a map. Implementation strategies are, of course, endless and future pedagogical studies need to explore in more detail the various approaches to the teaching and learning of motion expression.

The pedagogical approach suggested above would be consistent with previous applications of cognitive linguistics to the teaching of Spanish as a second language. Good examples of such practice are Alonso-Raya et al. (2005, 2nd Edition 2011) in their innovative Gramática básica del estudiante de español, and Castañeda et al. (2014). The research findings in this paper help to inform such a pedagogical approach and may help learners avoid incorrect form-meaning mappings and raise their linguistic awareness of conceptual domains prone to cross-linguistic influence.

\section{Funding}

This research was supported by Grants FFI2010-14903 and FFI2013-45553-C3-1-P from the Spanish Ministry of Economy and Competitiveness (MovEs project).

\section{Notes}

1. See Mosca (2013) on the complexity of the notion of satellite in Italian and the typological evolution from Latin.

2. Examples (3) and (4) are taken from Hijazo-Gascon (2011: 230-231).

3. A complete overview of different studies on thinking for speaking in the acquisition of Spanish as a second language is found in Cadierno and Hijazo-Gascon (2013).

4. The external assessors were Spanish teachers at the Instituto Cervantes, an institution specialised in teaching Spanish as a foreign language and certifiying the competence of students in this language. 
5. Encorrer derives from the Latin verb incurrere 'run towards', 'bump into' (Arnal-Purroy and Laguens-Gracia 2012). This is still present in Aragonese and in the variety of Spanish spoken in Aragon.

6. Since the use of percentages can be problematic in statistics, the arcsine formule is applied. The values are then transformed into angle values (radians).

7. In this analysis, the $\alpha$ level was set at .05, as in the Kruskal-Wallis test.

8. Particular attention was paid to the 'owl episode' in The Frog Story, a classical analysis in the field (Slobin 2014). No significant differences were found among native and learners groups in relation to their Manner expression for this episode; for example, none of the participants used a Manner verb in Spanish to describe the scene with the owl flying out of a hole in a tree.

9. The status of satellites and prepositions has been widely discussed in the literature. See Croft et al. (2010), Beavers et al. (2010) and Filipović (2007).

10. There are other constructions that can be transferred directly from French and Italian, such as dejar caer 'leave fall' (IT: lasciare cadere, FR: laisser tomber). This construction implies a lesser degree of agent intentionality. See Ibarretxe-Antunano and Hijazo-Gascón (2012) on caused motion in Spanish.

\section{References}

Alonso-Raya, R., A. Castañeda-Castro, P. Martínez-Gila, L. Miquel-López, J. Ortega-Olivares and P. Ruiz-Campillo. 2005. Gramática Básica del Estudiante de Español. (2nd ed., 2011). Barcelona: Difusión.

Beavers, J., B. Levin and S.-W. Tham. 2010. The typology of motion expressions revisited. Journal of Linguistics 44: 183-316.

Berman, R. and D.I. Slobin (eds.) 1994. Relating Events in Narrative. A Cross Linguistic Developmental Study. Hillsdale, NJ: Lawrence Erlbaum.

Brown, A. 2007. Crosslinguistic influence in first and second languages: convergence in speech and gesture. Unpublished PhD diss., Max Planck Institute for Psycholinguistics/Boston University.

Cadierno, T. 2004. Expressing motion events in a second language: a cognitive typological perspective. In Cognitive Linguistics, Second Language Acquisition and Foreign Language Teaching, ed. M. Achard and S. Niemeier, 13-49. Berlin: Mouton de Gruyter.

Cadierno, T. 2008. Motion events in Danish and Spanish: a focus on form pedagogical approach. In Cognitive Approaches to Pedagogical Grammar, ed. S. de Knopp and T. D. Rycker, 239-275. Berlin: Mouton de Gruyter.

Cadierno, T. 2010. Motion in Danish as a second language: does the Learner's L1 make a difference? In Linguistic Relativity in Second Language Acquisition. Thinking for Speaking, ed. Z. Han and T. Cadierno, 1-33. Bristol: Multilingual Matters.

Cadierno, T. and A. Hijazo-Gascón. 2013. Cognitive approaches to second language Spanish. A focus on thinking-for-speaking. In The Handbook of Spanish Second Language Acquisition, ed. K. Geeslin, 96-110. New York: Wiley.

Cadierno, T. and P. Robinson. 2009. Language typology, task complexity and the development of L2 lexicalisation patterns for describing motion events. Annual Review of Cognitive Linguistics 7: 245-276.

Cadierno, T. and L. Ruiz. 2006. Motion events in Spanish L2 acquisition. Annual Review of Cognitive Linguistics 4: 183-216.

Cardini, F.E. 2008. Manner of motion saliency: an inquiry into Italian. Cognitive Linguistics 19, no. 4: 533-569.

Castañeda, A., Z. Alhmoud, I. Alonso, J. Casellas, M. Dolores Chamorro, L. Miquel and J. Ortega. 2014. Enseñanza de Gramática Avanzada de ELE: Criterios y Recursos. Madrid: SGEL.

Cini, M. (ed.) 2008. I Verbi Sintagmatici in Italiano e Nelle Varietà Dialettali. Stato dell'arte e Prospettive di Ricerca. Frankfurt: Peter Lang.

Croft, W., J. Bardal, W. Hollmann, V. Sotirova and C. Taoka. 2010. Revising Talmy's typological classification of complex constructions. In Contrastive Studies in Construction Grammar, ed. H.C. Boas, 201-236. Amsterdam: John Benjamins.

Ellis, R. 1994. The Study of Second Language Acquisition. Oxford: Oxford University Press.

Filipović, L. 1999. Language-specific expression of motion and its use in narrative texts. Unpublished MA thesis. Faculty of Modern and Medieval Languages, University of Cambridge. 
Filipović, L. 2007. Talking about Motion: A Crosslingual Investigation of Lexicalisation Patterns. Amsterdam: John Benjamins.

Filipović, L. 2011. Speaking and remembering in one or two languages: bilingual vs. monolingual lexicalisation and memory for motion events. International Journal of Bilingualism 15, no. 4: 466-458.

Filipović, L. 2013. Typology as a continuum: intratypological evidence from English and SerboCroatian. In Variation and Change in the Encoding of Motion events, ed. J. Goschler and A. Stefanowitsch, 17-38. Amsterdam: John Benjamins.

Filipović, L. and I. Ibarretxe-Antuñano. 2015. Motion. In Mouton Handbook of Cognitive Linguistics, ed. E. Dabrowska and D. Divjak. Berlin: Mouton de Gruyter.

Filipović, L. and I. Vidaković. 2010. Typology in the L2 classroom: second language acquisition from a typological perspective. In Inside the Learner's Mind: Cognitive Processing in Second Language Acquisition, ed. M. Pütz and L. Sicola, 269-291. Amsterdam: John Benjamins.

Gullberg, M., H. Hendriks and M. Hickman. 2008. Learning to talk and gestures about motion in French. First Language 28, no. 2: 200-236.

Hasko, V. 2010. The role of thinking for speaking in adult L2 speech: the case of (non)unidirectionality encoding by American learners of Russian. In Linguistic Relativity in Second Language Acquisition. Thinking for Speaking, ed. Z. Han and T. Cadierno, 34-58. Bristol: Multilingual Matters.

Hijazo-Gascón, A. 2011. La expresión de eventos de movimiento y su adquisición en segundas lenguas. Unpublished PhD diss., Department of Hispanic and General Linguistics, Universidad de Zaragoza.

Hijazo-Gascón, A. and I. Ibarretxe-Antuñano. 2013a. Las lenguas románicas y la tipología de los eventos de movimiento. Romanische Forschungen, 4: 465-494.

Hijazo-Gascón, A. and I. Ibarretxe-Antuñano. 2013b. Same family, different paths: intratypological differences in three Romance languages. In Variation and Change in the Encoding of Motion Events, ed. J. Goschler and A. Stefanowitsch, 39-54. Amsterdam: John Benjamins.

Hohestein, J., A. Eisenberg and L. Naigles. 2006. Is he floating across or crossing afloat? Cross-influence in L1 and L2 in Spanish-English bilingual adults. Bilingualism: Language and Cognition 9: 249-261.

Iacobini, C. 2009. The role of dialects in the emergence of Italian phrasal verbs. Morphology 19, no. 1: 15-44.

Iacobini, C. and F. Masini. 2007a. The emergence of verb-particle constructions in Italian: locative and actional meanings. Morphology 16, no. 2: 155-188.

Iacobini, C. and F. Masini. 2007b. Verb-particle constructions and prefixed verbs in Italian: typology, diachrony and semantics. In On-line Proceedings of the Fifth Mediterranean Morphology Meeting (MMM5) Fréjus, 15-18 September 2005, ed. G. Booij, L. Ducceschi, B. Fradin, E. Gevara, A. Ralli and S. Scalise, 157-184. Bologna: Università degli Studi di Bologna.

Ibarretxe-Antuñano, I. 2009a. Path salience in motion events. In Crosslinguistic Approaches to the Psychology of Language: Research in the Tradition of Dan Isaac Slobin, ed. J. Guo,

E. Lieven, N. Budwig, S. Ervin-Tripp, K. Nakamura and S. Ozcaliskan, 403-414. New York: Psychology Press.

Ibarretxe-Antuñano, I. 2009b. Lexicalisation patterns and sound symbolism in Basque. In Trends in Cognitive Linguistics: Theoretical and Applied Models, ed. J. Valenzuela, A. Rojo and C. Soriano, 239-254. Hamburg: Peter Lang.

Ibarretxe-Antuñano, I. (ed.). forthcoming. Motion and Space across Languages and Applications. Amsterdam: John Benjamins.

Ibarretxe-Antuñano, I. and A. Hijazo-Gascón. 2012. Variation in motion events: theory and applications. In Space and Time across Languages and Cultures, Volume I: Linguistic Diversity, ed. L. Filipović and K.M. Jaszcolt, 349-371. Amsterdam: John Benjamins.

Jarvis, S. 2000. Methodological rigor in the study of transfer. Identifying L1 influence in the interlanguage lexicon. Language Learning 50, no. 2: 245-309.

Jarvis, S. 2010. Comparison-based and detection-based approaches to transfer research. In Eurosla Yearbook 10, ed. L. Roberts, M. Howard, M. O'Laoire and D. Singleton, 169-172. Amsterdam: John Benjamins.

Jarvis, S. and A. Pavlenko. 2008. Crosslinguistic Influence in Language and Cogntion. New York: Routledge. 
Kellerman, E. 1995. Crosslinguistic influence: transfer to nowhere? Annual Review of Applied Linguistics, 21: 47-77.

Kopecka, A. 2004. Étude typologique de l'expression de l'espace: localisation et déplacement en français et en polonais. Unpublished $\mathrm{PhD}$ diss., Sciences du Langage, Université Lumière Lyon 2.

Kopecka, A. 2006. The semantic structure of motion verbs in French: typological perspectives. In Space in Languages: Linguistic Systems and Cognitive Categories, ed. M. Hickmann and S. Robert, 83-101. Amsterdam: John Benjamins.

Kopecka, A. 2009. L'expression du déplacement en français: l'interaction des facteurs sémantiques, aspectuels et pragmatiques dans la construction du sens spatial. Langages 173: 54-75.

Larrañaga, P., J. Trefers-Daller, F. Tidball and M.C. Gil Ortega. 2011. L1 transfer in the acquisition of Manner and path in Spanish by native speakers of English. International Journal of Bilingualism 16, no. 1: 117-138.

Long, M.H. 1991. Focus on form: a design feature in language teaching methodology. In Language Research in a Cross-Cultural Perspective, ed. K. de Bot, R.B. Ginsberg, and C. Kramsch, 39-52. Amsterdam: John Benjamins.

MacWithney, B. 2000. The CHILDES Project: Tools for Analysing Talk (3rd ed.) Mahwah, NJ: Lawrence Erlbaum Associates.

Masini, F. 2005. Multi-word expressions between syntax and the lexicon: the case of Italian verb-particle constructions. SKY Journal of Linguistics 18: 145-173.

Miquel-López, L. and J. Ortega-Olivares. 2014. Actividades orientadas al aprendizaje explícito de recursos gramaticales en niveles avanzados de E/LE. In Enseñanza de Gramática Avanzada de ELE. Criterios y Recursos, ed. A. Castañeda, Z. Alhmoud, I. Alonso, J. Casellas, M.D. Chamorro, L. Miquel and J. Ortega, 89-162. Madrid: SGEL.

Montrul, S. 2001. Agentive verbs of Manner of motion in Spanish and English as second languages. Studies in Second Language Acquisition 23: 171-206.

Mosca, M. 2012. Italian motion constructions: different functions of 'particles'. In Space and Time across Languages and Cultures, Volume I: Linguistic Diversity, ed. L. Filipović and K.M. Jaszcolt, 373-393. Amsterdam: John Benjamins.

Navarro, S. and E. Nicoladis. 2005. Describing motion events in adult L2 Spanish narratives. In Selected Proceedings of the 6th Conference on the Acquisition of Spanish and Portuguese as First and Second Languages, ed. D. Eddington, 102-107. Somerville, MA: Cascadilla Proceedings Project.

Negueruela, E., J. Lantolf, S. Rehn Jordan and J. Gelabert. 2004. The 'private function' of gesture in second language speaking activity: a study of motion verbs and gesturing in English and Spanish. International Journal of Applied Linguistics 14: 113-147.

Nicoladis, E. and F. Brisard. 2002. Encoding motion in gestures and speech: are these differences in bilingual children's French and English? In Space in Language. Location, Motion, Path and Manner. The Proceedings of the 31st Stanford Child Language Research Forum, ed. E.V. Clark, 60-68. Stanford, CA: CSLI Publications.

Ochsenbauer, A.K. 2010. The impact of language-specifictors in first language acquisition: the expression of motion in French and German. Unpublished PhD diss., Université Paris 8 Vincennes and Ludwig-Maximilians-Universität München.

Odlin, T. 1989. Language Transfer: Cross-linguistic Influence in Language Learning. Cambridge: Cambridge University Press.

Özçalışkan, Ş. and D. Slobin. 2003. Codability effects on the expression of Manner of motion in Turkish and English. In Studies in Turkish Linguistics, ed. A.S. Özsoy, E.E. Taylan, A. Koç, D. Akar and M. Nakipoğlu-Demiralp., 259-270. Istanbul: Boğaziçi University Press.

Porquier, R. 2001. 'Il m'a sauté dessus', 'je lui ai couru après': un cas de postposition en français. Journal of French Language Studies, 11: 123-134.

Porquier, R. 2003. 'Gli corro dietro/Je lui cours après'. A propos d'une construction verbale spécifique en italien et en français. In Il Verbo Italiano. Studi Diacronici, Sincronici, Contrastivi, Didattici, ed. M. Giacomo-Marcellesi and A. Rocchetti, 491-500. Rome: Bulzoni.

Pourcel, S. and A. Kopecka. 2005. Motion expression in French: typological diversity. Durham and Newcastle Working Papers in Linguistics 11: 139-153.

Real Academia Española. 2005. Diccionario Panhispánico de Dudas. Madrid: Santillana. 
Schwarze, C. 1985. Uscire e andare fuori: struttura sintattica e semantica lessicale. In Sintassi e Morfologia della Lingua Italiana d'Uso. Teoria ed Applicazioni Descrittive. SLI XXIV, ed. A. Franchi De Bellis and L.M. Savoia, 355-371. Rome: Bulzoni.

Schwarze, C. 2008. I verbi sintagmatici: prospettive di ricerca. In I Verbi Sintagmatici in Italiano e Nelle Varietà Dialettali. Stato dell Arte e Prospettive di Ricerca, ed. M. Cini, 209-223. Frankfurt: Peter Lang.

Sebastián, E. and D.I. Slobin. 1994. Development of Spanish forms: Spanish. In Relating Events in Narrative: A Crosslinguistic Developmental Study, ed. R. Berman and D.I. Slobin, 239-284. Hillsdale, NJ: Lawrence Erlbaum.

Simone, R. 1996. Esistono verbi sintagmatici in italiano? Cuadernos de Filología Italiana 3: 47-61. Simone, R. 2008. Verbi sintagmatici come costruzione e come categoría. In I Verbi Sintagmatici in Italiano e Nelle Varietà Dialettali. Stato dell' Arte e Prospettive di Ricerca, ed. M. Cini, 13-30. Frankfurt: Peter Lang.

Slobin, D.I. 1991. Learning to think for speaking. Native language, cognition and rhetorical style. Pragmatics 1: 7-29.

Slobin, D.I. 1996a. Two ways to travel: verbs of motion in English and Spanish. In Grammatical Constructions: Their Form and Meaning, ed. M. Shibatani and S.A. Thompson, 195-317. Oxford: Clarendon Press.

Slobin, D.I. 1996b. From 'thought and language' to 'thinking for speaking'. In Rethinking Linguistic Relativity, ed. J. Gumperz and S. Levinson, 70-96. Cambridge: Cambridge University Press.

Slobin, D.I. 1997. Mind, code and text. In Essays on Language Function and Language Type: Dedicated to T. Givón, ed. J. Bybee, J. Haiman and S.A. Thompson, 437-467. Amsterdam: John Benjamins.

Slobin, D.I. 2000. Verbalized events. A dynamic approach to linguistic relativity and determinism. In Evidence for Linguistic Relativity, ed. S. Niemeier and R. Dirven, 107-138. Amsterdam: John Benjamins.

Slobin, D.I. 2003. Language and thought online: some consequences of linguistic relativity. In Language in Mind: Advances in the Investigation of Language and Thought, ed. D. Gentner and S. Goldin-Meadow, 157-191. Cambridge, MA: MIT Press.

Slobin, D.I. 2004. The many ways to search for a frog: linguistic typology and the expression of motion events. In Relating Events in Narrative: Typological and Contextual Perspectives, ed. S. Strömqvist and L. Verhoeven, 219-357. Hillsdale, NJ: Lawrence Erlbaum.

Slobin, D.I. 2006. What makes Manner of motion salient? Explorations in linguistic typology, discourse and cognition. In Space in Languages: Linguistic Systems and Cognitive Categories, ed. M. Hickmann and S. Robert, 59-82. Amsterdam: John Benjamins.

Eprearo:Tipologie di lessicalizzazione degli eventi di moto nelle lingue dell'Area linguistica Carlomagno. In Prospettive Nello Studio del Lessico Italiano: Atti del IX Congresso SILFI, Firenze, 14-17 Giugno 2006, ed. E. Crespi, 367-372. Florence: Firenze University Press.

Strömqvist, S. and L. Verhoeven (eds.) 2004. Relating Events in Narrative. Typological and Contextual Perspectives. Hillsdale, NJ: Lawrence Erlbaum Associates.

Talmy, L. 1985. Lexicalisation patterns: semantic structure in lexical forms. In Language Typology and Syntactic Description, Vol. 3: Grammatical Categories and the Lexicon, ed. T. Shopen, 36-149. Cambridge: Cambridge University Press.

Talmy, L. 1991. Path to realisation: a typology of event conflation. In Proceedings of the Seventeenth Annual Meeting of the Berkeley Linguistic Society, ed. L.A. Sutton and R. Shields, 480-519. Berkeley, CA: Berkeley Linguistics Society.

Talmy, L. 2000. Toward a Cognitive Semantics. Cambridge, MA: The MIT Press. 
Motion verbs used by L1 Spanish speakers

acercarse 'approach', acabar 'end up', acostarse 'lie down (in bed)', aparecer 'turn up', apoyarse 'lean on', bajar 'go down', caer 'fall', caerse 'fall', correr 'run', coger 'take', empujar 'push', echarse 'lie down', encorrer 'chase running', escaparse 'escape', esconder 'hide', esconderse 'hide oneself', frenar 'brake', huir 'flee', introducirse 'insert oneself', ir 'go', irse 'go', lanzar 'throw', lanzarse 'throw oneself', llegar 'arrive', llevar 'carry', llevarse 'carry', marcharse 'go away' meterse 'get into', mover 'move', pasear 'stroll', pegar un salto 'jump', perseguir 'chase', salir 'exit', saltar 'jump', subir 'go up', subirse 'go up', tirar 'throw', tropezarse 'trip', volver 'come back', volverse 'come back'

Motion verbs used by L1 Italian speakers in L2 Spanish

acercarse 'approach', adelantar 'overtake', apoyarse 'lean on', caer 'fall', caerse 'fall', coger 'take', correr 'run', conducir 'lead', colgar 'bahgir, 'throw', encontrarse 'find oneself', escapar

'escape', escaparse 'escape', esconder 'hide', huir 'flee', huirse*, incorporarse 'sit/get up', ir 'go', irse 'go', levantarse 'get up', llegar 'arrive', llevar 'carry', llevarse 'carry', pararse 'stop', perseguir 'chase', salir 'exit', salirse*, saltar 'jump', seguir 'follow', subir 'go up', subirse 'go up', tirar 'throw', tomar 'take', traer 'bring', trepar 'climb up', volar 'fly' and volver 'come back'

Motion verbs used by L1 French speakers in L2 Spanish

acercarse 'approach', agitar 'shake', aparecer 'turn up', apoyarse 'lean on', andar 'walk', arrengarse*, arrodillarse 'kneel', bajar 'go down', caer 'fall', caerse 'fall', cargar 'load', coger 'take', colgar 'hang', correr 'run', dejar 'leave', desaparecer 'disappear', echar 'throw', encontrarse 'find oneself', enderezarse 'straighten up', entrar 'enter', escaparse 'escape', estoparse*, huir 'flee', huirse*, ir 'grs'e, 'go', lanzar 'throw', levantarse 'get up', llegar 'arrive', llevar 'carry', llevarse 'carry', marcharse 'go away', meterse 'get into', pararse 'stop', perseguir 'chase', ponerse 'place oneself', salir 'exit', saltar 'jump', seguir 'follow', sentar 'sit down', subir 'go up', subirse 'go up', tirar 'throw', tomar 'take', traer 'bring', trepar 'climb up' and volver 'come back'

Verbs used by L1 German speakers in L2 Spanish

acercarse 'approach', acostarse 'lie down (on bed)'a,ndar 'walk', aparecer 'turn up', arrodillarse 'kneel', caer 'fall', caerse 'fall', correr 'run', cribar*, cambiar su posición 'change one's position', perder el equilibrio 'lose one's balance', darse un salto* 'give oneself a jump' (lit.), desaparecer 'disappear', dirigirse 'lead', encontrarse 'find oneself', escapar 'escape', escaparse 'escape', frenar 'brake', huir 'flee', huirse*, ir 'go', irse 'go', levantarse 'get up', llegar 'arrive', llevar 'carry', llevarse 'carry', marcharse 'go awaymontar 'ride', pararse 'stop', perseguir 'chase', ponerse "put oneself', quitar 'take from', regresarse 'come back', salir 'exit', saltar 'jump', seguir 'follow', subir 'go up', sujetarse 'hold on', tirar 'throw', tomar 'take', traer 'bring', venir 'come' and volar 'fly'

Notes: A number of the Spanish verbs produced by the L2 speakers are non-target-like forms and these are marked with an asterisk $\left(^{*}\right)$ in the lists above. These lexical creations are mostly due to L1 transfer or to communicative strategies. For the most part, they were counted as 'neutral' verbs to avoid mistaken interpretations about the communicative intentions of the participants, for example in the case of arrengarse and cribar used by an L1 French and an L1 German speaker, respectively. Only estoparse, used by a French speaker, was interpreted as 'stop' since it seemed a clear transfer from the French verb stopper 'to stop'. 